\title{
Consumers' Opinion of Inflation Bias Due to Quality Improvements in Transition in the Czech Republic
}

\author{
Jan Hanousek and Randall K. Filer ${ }^{*}$
}

August 2001

\begin{abstract}
Substantial understatement of the degree of quality improvement during transition, and, therefore, a substantial overstatement of inflation rates has resulted in a serious downward bias in estimates of the rate of growth of post-communist economies. The move to free markets has apparently improved consumers' welfare more by improving what they can purchase than by increasing how much they can purchase. Examining 63 products, focus group respondents in the Czech Republic reported that if they were to purchase the 1990 quality product today they would only be willing to do so at a average of 54 per cent of the current price for the current quality product. This implies that the actual increase in prices for the decade for these products 66 per cent instead of the official 139 per cent. Overall, mismeasurement of quality changes may have understated Czech growth rates during the first decade after communism by as much as 5 percentage point per year.
\end{abstract}

\begin{abstract}
Abstrakt
Příliš nízké odhady vlivu kvality zboží na jeho cenu během přechodného období mají vliv na výrazně vyšší hodnoty inflace a tím pádem nižší růst hrubého národního produktu $\mathrm{v}$ přechodových ekonomikách. Přechod $\mathrm{k}$ tržní ekonomice měl $\mathrm{z}$ hlediska spotřebitelů větší vliv na to, co si mohou koupit než o kolik se zvýšila cena nabízeného zboží. Skupiny spotřebitelů v České republice zkoumaly 63 produktů a dospěly $\mathrm{k}$ závěru, že pokud by nakupovaly produkty z roku 1990 v současnosti, byly by ochotny platit pouze $54 \%$ současné ceny. To znamená, že skutečný růst cen pro tuto skupinu zboží by byl pouze $66 \%$ místo oficiálních $139 \%$. Celkově můžeme říci, že vliv vzrůstající kvality zboží mohl mít vliv na růst české ekonomiky až 5 procent ročně.
\end{abstract}

JEL: $\quad$ C82, E31, P24

Keywords: Inflation Bias, Quality Change, Transition Economies

\footnotetext{
* Jan Hanousek is Citibank Associate Professor of Economics at CERGE-EI, a joint workplace of Charles University and The Academy of Sciences of the Czech Republic, Politických vězňu 7, 11121 Prague 1, Czech Republic, e-mail: jan.hanousek@cerge.cuni.cz. Randall K. Filer is Professor of Economics at Hunter College and The Graduate Center, City University of New York and CERGE-EI, e-mail: rfiler@hunter.cuny.edu. Both are Research Associates of the William Davidson Institute. This research was supported in part by grants P978119-R from the PHARE/ACE program of the European Union and II/75831 from the Volkswagen Foundation. ${ }^{+}$The authors gratefully acknowledges comments from participants in the PHARE/ACE workshop held at CERGE-EI in February 2000 and from Michael Burda, Ivona Kovacs and Emil Stavrev on earlier drafts of this paper.
} 


\section{Introduction and Motivation}

Measurement, or more importantly mismeasurement, of inflation poses fundamental problems for understanding the transition from planned to market economies since the collapse of communism. As Filer and Hanousek (2000) have pointed out, eliminating even a relatively minor overstatement of the inflation rate by $20 \%$ "would show that every country in the region grew during the 1990s, turning a story of decline and disruption into one of growth and hope.” (p. 293, see also Duchene and Gros, 1994). Among the sources of upward bias in inflation measures during transition, quality changes are especially important.

Quality improvement bias occurs when statistical agencies fail to adequately reflect improvements in product quality, thereby attributing the part of a price increase that is due to improved quality to inflation instead. Quality improvements are likely to be an especially important source of bias in transition economies, largely because initial quality levels were so low. As Stiglitz (1994) and others have pointed out, because specification of quality is much more difficult than specification of quantities, there was a natural tendency in command economies, where personal rewards of management depend on plan fulfillment, to economize on effort and other resources by continually reducing quality while still meeting numerical quantity goals for imprecisely specified goods.

Quality improvement is difficult to measure in even the best of circumstances when products are generally stable and the issue is discrete replacement of existing products with new, improved models. During the transition quality changes have occurred continuously in even the most basic products. In 1990, for example, "fresh" milk sold in the Czech Republic came in a plastic container that gave the milk a chemical smell and resulted in the 
milk spoiling in less than two days. By 1996 fresh milk from the same dairy came in paperpack that assured a natural smell and durability that was guaranteed for four days. How much of the price increase in milk should be attributed to inflation and how much to the fact that consumers were provided a better tasting and longer lasting product?

Similarly, much of the increased diversity of products available following the fall of communism is properly regarded as quality improvement. Consider, for example, fashion items, such as a woman's cotton dress or handbag. In 1990 such "fashion" products were widely regarded as being deficient with respect to style, pattern, color and quality in general. By 1995 there was a significant increase in both the quality and variety of fashion products available. How much more was a woman willing to pay for increased choice when purchasing fashion items? Similarly, how much more would consumers living under communism have been willing to pay for admission to a movie if that movie had been the one they most wanted to see rather than the one that had been approved for showing by local censors?

Although there exist several procedures specifically designed for adjusting for quality changes when measuring price changes (see Nordhaus, 1998, Reinsdorf et. al. 1996, Lancaster, 1977 and Griliches, 1971), none is likely to capture the extent and nature of quality changes during the transition as a chronic shortage economy characterized by lowquality goods adapts to world market conditions.

1) The most common adjustment is based on simultaneous observation of prices for both the old and new versions of the product at a time when both are available. The price change associated with quality change is estimated as the difference in the 
market prices in this overlapping period. At the moment the new product substitutes for the old one in the consumer basket the price difference between the new product's price in period $t$ and the old product's price in period $t-1$ is divided between a pure price increase and the quality change as estimated in the overlapping period:

$$
\begin{aligned}
& Q_{t-1}^{\text {new }}-p_{t-1}^{\text {old }}=\Delta \\
& p_{t}^{\text {new }}-p_{t-1}^{\text {old }}=\delta p_{t}+\Delta
\end{aligned}
$$

The overlap pricing method may produce distorted results if a producer initially offers the new version at the same price as the previous one but later adjusts prices to reflect true quality differences. In addition, it requires that both the old and new version of a product be traded in the same outlet at the same time, something that is unlikely to happen with respect to regular upgrading of quality in basic consumer goods.

2) When a new product is not comparable with the old product, prices indices can be computed excluding the new product. First a price index $\delta p_{t}^{n-1}$ based only on other, similar goods is calculated for the month when the substitution was made, ignoring the product which is being replaced. Then the percentage change in price between the new and old versions of the product is decomposed into a price increase effect assumed to be the same as that for other products of a similar nature and a residual effect of quality changes.

3) For specific products, mostly durables such as cars, computers, VCRs, or microwaves, hedonic regressions are used. In this procedure price is regressed on 
characteristics of the specific good. The coefficients given by this price-quality relationship are used to deduce the "true" value of the new products based on their characteristics by applying estimated coefficients to measured differences in characteristics between the old and the new referent goods in the consumer price basket (see, for example, Feenstra 1995, Triplett 1990, and Kahn, Lang 1988). The U.S. Bureau of Labor Statistics has used such adjustments for a number of years and has recently announced a major expansion of quality adjustments derived from hedonic models (see Fixler et. al. 1999 and the series of studies for various products reported at http://stats.bls.gov/cpihome.htm as well as Schwartz and Scafidi 2001). Such a methodology requires that a wide variety of models of a product with differing identifiable characteristics be available in the market at a given time.

4) The last method is called direct quality adjustment. This method is based on the market value of measurable differences in physical characteristics when such differences have been priced independently. Such adjustments can be made only when the quality improvement involves previously optional characteristics becoming bundled into the standard version of the product. Examples might include air bags and anti-lock brakes for cars, or modems and CD-ROM drives for computers.

None of these techniques are appropriate for capturing the sort of quality improvements in basic commodities that were common in transition economies. Every-day products such as milk do not have the extensive set of measurable characteristics needed for hedonic regressions while small continuous changes in products (such as replacing pry-off caps with resealable twist off caps on jam jars) do not lead to the sort of observable changes 
needed for use of the overlap or temporary exclusion methods.

Indeed, between 1989 and 2000, the Czech Statistical Office engaged in a "hedoniclike" correction for quality change only once, in January 1995 when Škoda, the producer of the only automobile in the Czech consumer price basket, changed its main model from the Favorit, the last model designed by an independent Škoda, to the Felicia, the first model produced with design and engineering by its new owners, Volkswagen. Table 1 shows the official adjustment made when this replacement took place. It looks like a typical hedonic adjustment with one critical difference. The characteristics evaluated and the weights assigned to each were not derived from regression analysis but rather simply "made up" by an engineering firm hired by the Czech Statistical Office. Reflecting a communist mentality based on materials balances, the key factors are heavily influenced by size. Using these criteria the Czech Statistical Office deemed the Felicia to be 5.01\% higher quality than the Favorit. Furthermore, using the same criteria, the Felicia is over 10\% higher quality than the Porsche 911 Turbo, due largely to the latter's small trunk size! Mikulcová-Šerešová (2001) reports that a true hedonic regression using only measurable characteristics finds the Felicia to be approximately $17 \%$ higher quality than the Favorit. Of course, even a proper hedonic regression cannot capture the quality improvement inherent in the fact that the latter car was built to the higher standards imposed by Volkswagen. Thus, the market prices at the time the Felicia was introduced differed by some $50 \%$.

Other than this single "hedonic" adjustment, in the latter part of the 1990s the Czech Statistical Office omitted items from calculations of the consumer price index in the months when field samplers reported that they replaced the representatives used. There exists, 
however, no documentation of when this procedure was adopted and personal conversations with individuals responsible for producing the CPI series indicate that it was not used at the start of the transition. We will discuss the cumulative impact of these adjustments below. It is clear, however, that the techniques used by the Czech Statistical Office will have missed a great deal of the quality improvement that was an important part of the introduction of a market economy and that, indeed, no conventional adjustment mechanism can capture these quality changes. We must, therefore, search for a new, innovative way to capture quality improvements in the transition environment.

\section{Consumers' Views of Quality Changes}

We start with the rather obvious assumption that the best way to ascertain the extent to which consumers believe the quality of the products they purchase has changed is to ask the consumers themselves. We do this using focus groups in the Czech Republic. Focus groups have previously been used to determine the price consumers might be willing to pay for various products and services such as environmental amenities. ${ }^{1}$ Among enterprises they are widely used to investigate consumer acceptance of potential new products prior to their launch, including issues of appropriate pricing for such products. ${ }^{2}$ Thus, it would seem appropriate to extend the methodology to investigate how consumers would value older,

\footnotetext{
${ }^{1}$ See Soderholm (2001), Hanley et. al. (2001), Kaplowitz and Hoehn (2001), Kontogianni et. al. (2001), Ortuzar, Iacobelli and Velez (2000), Chilton and Hutcheson (1999), Freeman and Rogers (1999), Beattie et. al (1998) Knoppers and Mathios (1998), and Kramer and Mercer (1997).

${ }^{2}$ See, for example, Bernacchi (2001) and Samel and Henthorne (1993) for examples and Feick et. al. (1995) for a use of focus groups in evaluating consumer experiences in the transition..
} 
presumably lower quality, products that are no longer on the market relative to how they value today's version of these products. In effect, we will be asking consumers: "given the price and quality bundle represented by a product sold today (and in the consumer basket used to determine the CPI today), what would be a reasonable price for the quality characteristics of the same product as they existed at the start of the transition were you able to purchase this older product today?"3 The difference in these prices represents the difference in the quality of the item, expressed in today's currency. Only price increases in excess of this difference can be said to represent true inflation.

We engaged a firm active in doing market research in the Czech Republic to conduct a series of focus group sessions between March and May 2001. Each group was composed of men and women aged 33 to 55 who were the head or spouse of the head of a household in 1990 and who had secondary or higher education. Each group consisted of six individuals

${ }^{3}$ Framing the question in this way raises the issue of differences between "willingness to pay" and "willingness to accept" valuations. In general it is believed that consumers value items more highly when asked what they would require to give them up (willingness to accept) versus what they would be willing to pay for an item they do not now have. If true, this would argue that the perceived value of quality differences would be higher when viewed retrospectively as we do than they would if evaluated at the start of transition since consumers already have access to the improved products. We are inclined to believe that this divergence is minimal for two reasons. First, differences between willingness to pay and willingness to accept have been shown to be smaller when close substitutes exist for the product in question (Shogren 1994, and Adamowicz, Bhardwaj and Macnab 1993). Surely there can be no closer substitutes than old and new versions of the same product. Secondly, the difference is generally assumed to arise from informational discrepancies between products with which consumers have experience and those that are unknown to them (Kolstad and Guzman 1999). In our case, consumers have full information on both the old and new versions of the products, having actually consumed both. 
and evaluated approximately ten independent products chosen to come from a variety of the major categories in the consumer basket.

Each focus group followed a similar script, dealing with one product at a time.

1) The moderator presented the product as it existed in 1990 (using a photo or the actual product if available). Group members were asked to recall this particular product and discuss its typical features and what they liked and/or disliked about it as users/consumers. The members of the group worked together to reach a consensus view regarding the characteristics of the earlier product.

2) The current (2001) version of the product was presented and the group discussed its characteristics and how they differ from the product as existed in 1990.

3) The moderator distributed a record sheet for the product under discussion and asked group members to carefully consider all the differences between the 2001 version of the product and the product as it existed in 1990. The moderator then revealed the current price of the 2001 version of the product and asked, "if both versions of the product were sold on the market today alongside each other what would you consider to be a fair and appropriate price for the 1990 version, provided that the 2001 version costs crowns?"

4) After the price was assigned individually by the respondents, the individual choices were discussed among the group. The moderator would probe to elicit discussion of why the participant's assigned the relative prices they did.

5) At the end of the session, after discussing about ten different products, respondents were ask to again individually evaluate and record their relative evaluations for each 
product. This gave respondents a chance to revise their evaluations in light of the group discussion and the patterns revealed across the several products being evaluated. We retained both the initial and revised evaluations although there were minimal differences. Results below are based on the revised figures.

\section{Results}

The Czech consumer price basket consists of approximately 750 individual referent items defined at a level such "mayonnaise" or "leather walking shoes for boys." There have been almost no changes in these items during the 1990s although the specific brand or model of the representative item may have been changed several times and may differ across different sample points (stores) at any given time. Our focus groups evaluated 63 items that comprised 16.2 per cent of the total weight in the consumer basket as of $1990 .{ }^{4}$

Table 2 reports the results for these 63 products. The third column shows the price of the referent good in official CSO data in 1990 while the fourth column shows the price for the same item in January 2001. The fifth column shows the percentage increase in prices between 1990 and 2001. As mentioned above, however, the Czech Statistical Office excluded item/store pairs from the CPI in months when there was an obvious change in the referent item sampled. Thus column 6 shows the official increase in the price index for each item after incorporating any adjustments made by the CSO, Column 7, which is the

\footnotetext{
${ }^{4}$ An additional three items were evaluated by the focus groups but have been excluded from the analysis because the groups concluded that the 1990 quality was so low that the proper 2001 price would be zero or negative, implying an infinite quality improvement. We have excluded these items from our analysis, thereby biasing our estimates of consumers' perceptions of average quality change towards zero.
} 
difference between Columns 5 and 6 , therefore, shows the increase in prices excluded by the Czech Statistical Office in their adjustment for quality changes through omitting months when referents were changed.

Columns 8 though 10 contain the heart of our research. Column 8 shows the median ${ }^{5}$ response among our focus group members to the question "what would be a fair price today for the 1990 version of product X, given the actual price charged today for the current version of the product?" Thus, column 9, showing the percentage difference between these hypothetical current prices for the 1990 version of the product and the actual market price for the current version of the product (column 4), represents consumers' opinion of the difference in quality between these two product versions in today's currency. Finally, column 10 indicates the percentage difference between the actual 1990 price of the product (column 3) and what consumers' would be willing to pay for the constant-quality version of the product today (column 8). As such, it represents the true cumulative inflation rate for this product purged of the effect of quality changes.

Looking at the first row of data in Table 2 makes the importance of adjusting for hidden quality improvements clear. In 1990 a liter of milk sold for 2.8 crowns while in 2001 it sold for 12 crowns according to official CSO price data. This was a 328.6 per cent increase as shown in column 5. There were no significant adjustments made by the CSO, so the official price increase used for calculating the CPI over this period was 332.5 percent as shown in column 6 . When consumers were asked to recall the characteristics including packaging, flavor and shelf life of milk as they existed in 1990 and evaluate how much they

${ }^{5}$ Results are virtually identical if we use the mean response instead. 
would be willing to pay for such milk today, they decided that 8 crowns would be a fair price given that milk with today's characteristics sold for 12 crowns. The value of the increased quality is the difference between today's price of 12 crowns and the hypothetical "fair" price for the older quality product of 8 crowns today or $50 \%$ as shown in column 9 . Thus, the actual price increase for milk of constant quality is not 328 per cent, but rather the 185.7 per cent shown in column 10 resulting from an increase from 2.8 crowns per liter in 1990 to a hypothetical price of 8 crowns for the 1990 product version today.

We asked focus groups about a variety of products from across the consumer basket. The items evaluated cannot be claimed to be random, but they do account for a sixth of the entire basket and were not explicitly selected to be ones with large presumed quality changes. The average price increase for all products we surveyed, weighted by their share in the consumer basket, was 149.99 percent, while the official increase in the CPI for these components after all adjustments by the Czech Statistical Office was 139.41 percent, implying that the CSO found only 7.05 per cent of the price increase to be due to quality improvements. Our focus group respondents, however, found the average quality improvement across the 63 products to be 84 percent. In other words, they reported that if they were to purchase the 1990 quality product today they would only be willing to do so at a average of 54 per cent of the current price for the current quality product. ${ }^{6}$ This implies that the actual increase in prices for the decade for these products 65.95 per cent instead of the official 139.41 per cent.

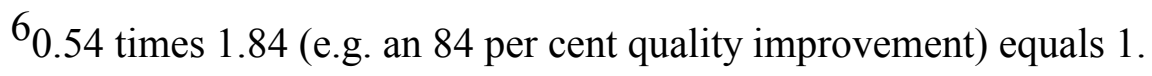


The results in Table 2 are grouped according to broad categories of goods. The patterns are intuitively appealing, giving confidence that the focus group methodology is sound. Reported quality improvements are smallest for food and beverages, averaging around 13 per cent. Thus, the vast majority of the price increase of somewhat over 100 per cent for these items was true inflation. Indeed, for some foodstuffs, our consumer groups reported no quality improvement or even a quality decline since the end of communism. Our respondents reported the greatest increase in quality for personal care products and recreational products, followed by clothing and home care products.

Across all products we surveyed, prices increased by 149.7 per cent between 1990 and early 2001. Adjustments made by the Czech Statistical Office reduced the measured inflation rate for these products to 139.4 per cent. Our respondents, however, believed that the quality of the products as they existed today was, on average, 84.2 per cent better than it had been in 1990 . Thus, the true price increase for constant quality products was only 65.7 per cent, less than half of the official price increase of 139.4 per cent for these items. ${ }^{7}$ If we assume that other items within each broad product group behaved in the same way as those we sampled, then scaling up the sampled items to reflect weights for the full consumer basket implies a slightly greater official index increase of 152.4 per cent, a quality improvement of 71.1 per cent, and a true price increase of 77.2 percent.

\footnotetext{
${ }^{7}$ While a seemingly high number, this proportion is fully consistent with that derived using an entirely different methodology for Romania in 2000, where consumers reported that income increases of less than half of the official inflation rate were sufficient to enable them to purchase as much as they were able to purchase the previous year (Filer and Hanousek 2001).
} 
Overall, it appears that the Czech Statistical Office has captured less than 20 percent of the quality change that our respondents believe has occurred. over the first decade of the transition. Extrapolated to the full consumer basket, the suggestion is that average growth rates in the Czech Republic during the 1990s may have been 5 per cent per year greater than the official figures suggest. Such an adjustment would have a major impact on beliefs about the success of the move to market economies

The reader is cautioned, however, to view the findings as preliminary. We have not sampled the full consumer price basket. ${ }^{8}$ More importantly, consumers were evaluating the quality of goods assuming that they were actually available and not assigning any reduction in quality for scarcity. As one group member said during the discussion, "well, you had to line up for them and couldn't always find baked goods, but when you did you knew they were fresh!" In effect, the true price increase should be substantially smaller than the apparent price increase in our data once search and scarcity (waiting) costs are factored into prices at the start of the transition. Obviously, this would make quality improvement an even more significant fraction of the real price change. The bottom line would remain, however, that a substantial understatement of the degree of quality improvement during transition, and, therefore, a substantial overstatement of inflation rates has resulted in a serious downward bias in estimates of the rate of growth of post-communist economies. The move to free

\footnotetext{
${ }^{8}$ Although even if there were no quality improvement in the remaining items in the consumer price basket, the biases we have identified in the 16 per cent of the basket we have studied would be sufficient to increase measured growth rates by 1.3 per cent a year over the full decade. Of course, the assumption that no other goods exhibited a quality increase is totally unjustified.
} 
markets has apparently improved consumers' welfare more by improving what they can purchase than by increasing how much they can purchase. 


\section{REFERENCES}

Adamowicz, Wiktor L., Vinay Bhardwaj and Bruce Macnab. 1993. "Experiments on the Difference between Willingness to Pay and Willingness to Accept," Land Economics. 69 (4): 416-27.

Beattie, Jane, J. Covey, P. Hopkins e. al. 1998. "On the Contingent Valuation of Safety and the Safety of Contingent Valuation," Journal of Risk and Uncertainty, 17 (1): $5-25$.

Chilton, S. M. and W. G. Hutchinson. 1999. "Do Focus Groups Contribute Anything to the Continent Valuation Process?" Journal of Economic Psychology, 20 (4): 46583.

Czech Statistical Office 1990-200. Consumer Price Indices: Specification of the Representatives and Their Weights in the Consumer Basket (in Czech), Prague, Czech Statistical Office, mimeo.

Duchene, G. and Gros, D. 1994. Cases of Output Decline in Reforming Economies, Center for European Policy Studies, Brussels.

Feenstra, Robert C. 1995. "Exact Hedonic Price Indexes," Review of Economics and Statistics, 116 (12): 3-12.

Fieck, Lawrence, Robin Higie Coulter and Linda L. Price. 1995. "Consumers in the Transition to a Market Economy: Hungary, 1989 - 1992.” International Marketing Review, 12 (5): 18-34.

Filer Randall K., and Hanousek Jan "Survey-based Estimates of Biases in Consumer Price Indices During Transition: Evidence from Romania" Prague: CERGE-EI Working Paper 178.

,2000. "Output changes and inflationary bias in transition,"Economic Systems, 24 (3): 285-294.

Fixler, Dennis, Charles Fortuna, John Greenlees and Walter Lane. 1999. "The Use of Hedonic Regressions to Handle Quality Change: The Experience of the U.S. CPI," Washington, DC: Bureau of Labor Statistics, mimeo (presented at $5^{\text {th }}$ meeting of the International Working Group on Price Indices). 
Freeman, Richard B. and Joel Rogers. 1999. What Workers Want, Ithaca: Cornell University Press.

Griliches, Zvi (ed) 1971. Price Indexes and Quality Change: Studies in New Methods of Measurement, Cambridge: Harvard University Press.

Hanley, N., G. Koop, B. Alvarez-Farizio et. al. 2001. "Go Climb a Mountain: An Application of Recreation Demand Modeling to Rock Climbing in Scotland," Journal of Agricultural Economics, 52 (1): 36-52.

Kahn, S. and Lang, K. 1988. "Efficient Estimation of Structural Hedonic Systems," International Economic Review, 29 (1): 157-166.

Kaplowitz, M. D. and Hoehn, J. P. 2001. "Do Focus Groups and Individual Interviews Reveal the Same Information for Natural Resource Valuation?", Ecological Economics; 36 (2): 237-247.

Kolstad, Charles D and Rolando M. Guzman. 1999. "Information and the Divergence between Willingness to Accept and Willingness to Pay," Journal of Environmental Economics and Management, 38 (1): 66-80.

Kontogianni, A., M. S. Skourtos, I. H. Langford et. al. 2001. "Integrating Stakeholder Analysis in Non-market Valuation of Environmental Assets," Ecological Economics, 37 (1): 123-38.

Kramer, Randall A. and Evan D. Mercer. 1997. "Valuing a Global Environmental Good: U.S. Residents' Willingness to Pay to Protect Tropical Rain Forests," Land Economics, 73 (2): 196-210.

Lancaster, K. 1977. "The Measurement of Changes in Quality," Review of Income and Wealth 23 (2): 157-172.

Leigey, Paul R. Jr. 1994. “Apparel Prices Indexes: Effects of Hedonic Adjustment,” Monthly Labor Review, 117 (5): 38-45.

Nordhaus William D. 1998. "Quality Change in Price Indexes", Journal of Economic Perspectives 12 (1):59-68

Ortuzar, Juan de Dios, Andres Iacobelli and Claudio Valeze, 2000. "Estimating Demand for a Cycle-Way Network," Transportation Reearch: Part A - Policy and Practice, 34 (5): 353-73. 
Reinsdorf, Marshall B. Paul Liegey and Kenneth J. Stewart. 1996. "New Ways of Handling Quality Change in the U.S. Consumer Price Index," Washington, DC: Bureau of Labor Statistics Working Paper 276.

Samel, Ben R. and Tony L. Henthorne. 1993. "The Process for Determining an ATM Pricing Strategy.” Journal of Retail Banking, 15 (2): 25-29.

Schwartz, Amy Ellen and Benjamin P. Scafidi. 2001. "Quality Adjusted Indices for Four Year Colleges," Washington, DC: Bureau of Labor Statistics Working Paper 337.

Shogren, Jason F. et. al. 1994. "Resolving Differences in Willingness to Pay and Willingness to Accept," American Economic Review. 84 (1): 255-70.

Soderholm, Patrik. 2001. "The Deliberative Approach in Environmental Valuation," Journal of Economic Issues. 35 (2): 487-95.

Stiglitz, Joseph E. 1994. Whither Socialism?, Cambridge, MIT Press.

Triplett, Jack E. 1990. "Hedonic Methods in Statistical Agency Environments," in E. R. Berndt and J. E. Triplett (eds) Fifty Years of Economic Measurement: The Jubilee Conference on Research in Income and Wealth, Chicago: University of Chicago Press for NBER. 
Table 1

The Czech Statistical Office Quality Adjustment of Skoda Favorit (Old Product) vs. Skoda Felicia (New Product)

\begin{tabular}{|c|c|c|c|c|c|c|c|}
\hline attributes & unit & Favorit & Felicia & $\begin{array}{c}\text { weights in } \\
\% \\
\end{array}$ & $\begin{array}{c}\text { Index of change of } \\
\text { attribute }\end{array}$ & $\begin{array}{c}\text { index of change in } \\
\text { utility }\end{array}$ & $\begin{array}{c}\text { weight } \mathrm{x} \text { utility } \\
\text { change }\end{array}$ \\
\hline length & $\mathrm{mm}$ & 3815 & 3855 & 5 & 101 & 101 & 5.05 \\
\hline width & $\mathrm{mm}$ & 1620 & 1635 & 5 & 101 & 101 & 5.05 \\
\hline height & $\mathrm{mm}$ & 1415 & 1415 & 5 & 100 & 100 & 5.00 \\
\hline wheelbase & $\mathrm{mm}$ & 2450 & 2450 & 3 & 100 & 100 & 3.00 \\
\hline $\begin{array}{l}\text { front track } \\
\text { distance/back track } \\
\text { distance }\end{array}$ & $\mathrm{mm}$ & $1420 / 1380$ & $1420 / 1380$ & 3 & 100 & 100 & $\mid 3.00$ \\
\hline capacity weight & $\mathrm{kg}$ & 450 & 450 & 5 & 100 & 100 & 5.00 \\
\hline $\begin{array}{l}\text { towed weight with } \\
\text { brakes }\end{array}$ & $\mathrm{kg}$ & 750 & 900 & 3 & 120 & 120 & 3.60 \\
\hline surface & $\mathrm{m}^{2}$ & 2.46 & 2.58 & 25 & 105 & 105 & 26.25 \\
\hline luggage capacity & $\mathrm{m}^{3}$ & 0.251 & 0.272 & 18 & 108 & 108 & 19.44 \\
\hline tank volume & 1 & 42 & 42 & 3 & 100 & 100 & 3.00 \\
\hline $\begin{array}{l}\text { coeff. of } \\
\text { aerodynamic drag } \mathrm{C}_{\mathrm{X}}\end{array}$ & & 0.409 & 0.346 & 8 & 85 & 118 & $\mid 9.44$ \\
\hline max. velocity & $\mathrm{km} / \mathrm{h}$ & 137 & 145 & 3 & 106 & 106 & 3.18 \\
\hline acceleration & $\mathrm{s}$ & 17 & 17 & 4 & 100 & 100 & 4.00 \\
\hline fuel consumption & $1 / 100 \mathrm{~km}$ & 7.1 & 7.1 & 10 & 100 & 100 & 10 \\
\hline
\end{tabular}

Overall index of change of utility measured by the CSO is $\mathbf{1 0 5 . 0 1}$ 
Table 2

Summary of focus group quality adjustment estimates

\begin{tabular}{|c|c|c|c|c|c|c|c|c|c|}
\hline $\begin{array}{l}\text { Product Description } \\
\text { (1) }\end{array}$ & $\begin{array}{c}\text { Weight } 1990 \\
(2)\end{array}$ & $\begin{array}{c}\text { Price } 1990 \\
\text { (3) }\end{array}$ & $\begin{array}{c}\text { Price } 2000 \\
\text { (4) }\end{array}$ & $\begin{array}{c}\text { \% Price Increase } \\
\text { (5) }\end{array}$ & $\begin{array}{c}\text { Index } \\
\text { Increase } \\
(6)\end{array}$ & $\begin{array}{c}\text { Captured } \\
\text { Change } \\
(7)\end{array}$ & \begin{tabular}{|c|} 
Today's Price \\
for 1990 Product \\
$(8)$
\end{tabular} & $\begin{array}{c}\text { \% Quality } \\
\text { Change } \\
\text { (9) }\end{array}$ & $\begin{array}{c}\% \text { Actual } \\
\text { Price Increase } \\
(10)\end{array}$ \\
\hline \multicolumn{10}{|l|}{ Food } \\
\hline milk & 3.5 & 2.8 & 12 & 328.57 & 332.54 & -3.97 & 8 & 50.00 & 185.71 \\
\hline bread & 5.7 & 3.6 & 14.48 & 302.22 & 314.23 & -12.01 & 14.5 & -0.14 & 302.78 \\
\hline roll & 7.4 & 0.5 & 1.6 & 220.00 & 224.8 & -4.80 & 1.2 & 33.33 & 140.00 \\
\hline pie & 1.1 & 0.8 & 2.5 & 212.50 & 192.53 & 19.97 & 2.9 & -13.79 & 262.50 \\
\hline chicken & 6.4 & 30.5 & 46.2 & 51.48 & 52.16 & -0.68 & 40 & 15.50 & 31.15 \\
\hline sausages & 2.5 & 39.6 & 71.45 & 80.43 & 77.44 & 2.99 & 65 & 9.92 & 64.14 \\
\hline yoghurt & 2.3 & 3.3 & 11.6 & 251.52 & 261.99 & -10.47 & 8 & 45.00 & 142.42 \\
\hline cheese & 3.2 & 32.5 & 110 & 238.46 & 187.17 & 51.29 & 110 & 0.00 & 238.46 \\
\hline mayonnaise & 1.4 & 3 & 8.5 & 183.33 & 177.37 & 5.96 & 6 & 41.67 & 100.00 \\
\hline rape-seed oil & 1.8 & 15.2 & 36.27 & 138.62 & 159.02 & -20.40 & 30.5 & 18.92 & 100.66 \\
\hline bananas & 4.3 & 17 & 27 & 58.82 & 58.09 & 0.73 & 27 & 0.00 & 58.82 \\
\hline coffee & 16.1 & 17.6 & 12.7 & -27.84 & -15.03 & -12.81 & 12.7 & 0.00 & -27.84 \\
\hline tea & 0.7 & 3.7 & 37.19 & 905.14 & 747.11 & 158.03 & 20 & 85.95 & 440.54 \\
\hline milk chocolate & 1.9 & 10.1 & 17.72 & 75.45 & 71.42 & 4.03 & 13.5 & 31.26 & 33.66 \\
\hline chewing gum & 1.4 & 5 & 8.75 & 75.00 & 75.49 & -0.49 & 2.8 & 212.50 & -44.00 \\
\hline ice cream & 0.7 & 32.3 & 97 & 200.31 & 141.82 & 58.49 & 97.5 & -0.51 & 201.86 \\
\hline ketchup & 0.5 & 6.6 & 45.21 & 585.00 & 609.33 & -24.33 & 40 & 13.03 & 506.06 \\
\hline Total & 68.3 & & & 110.94 & 111.08 & -0.14 & & 13.72 & 86.29 \\
\hline
\end{tabular}


Table 2

(continued)

\begin{tabular}{|c|c|c|c|c|c|c|c|c|c|}
\hline $\begin{array}{l}\text { Product Description } \\
\text { (1) }\end{array}$ & $\begin{array}{c}\text { Weight } 1990 \\
\text { (2) }\end{array}$ & $\begin{array}{c}\text { Price } 1990 \\
\text { (3) }\end{array}$ & $\begin{array}{c}\text { Price } 2000 \\
\text { (4) }\end{array}$ & $\begin{array}{c}\text { \% Price Increase } \\
\text { (5) }\end{array}$ & $\begin{array}{c}\text { Index } \\
\text { Increase } \\
\quad(6)\end{array}$ & $\begin{array}{l}\text { Captured } \\
\text { Change } \\
(7)\end{array}$ & $\begin{array}{c}\text { Today's Price } \\
\text { for } 1990 \text { Product } \\
(8)\end{array}$ & $\begin{array}{l}\text { \% Quality } \\
\text { Change } \\
\text { (9) }\end{array}$ & $\begin{array}{c}\% \text { Actual } \\
\text { Price Increase } \\
\text { (10) }\end{array}$ \\
\hline \multicolumn{10}{|l|}{ Drinks } \\
\hline carbonated water & 0.7 & 0.7 & 5.6 & 700.00 & 635.59 & 64.41 & 5.6 & 0.00 & 700.00 \\
\hline bottle of wine & 4.2 & 30 & 80 & 166.67 & 160.17 & 6.50 & 70 & 14.29 & 133.33 \\
\hline \multicolumn{10}{|l|}{ Clothes } \\
\hline cotton dress & 2.5 & 318.1 & 1521 & 378.15 & 323.6 & 54.55 & 500 & 204.20 & 57.18 \\
\hline bra & 1 & 91.1 & 384.81 & 322.40 & 250.56 & 71.84 & 82.5 & 366.44 & -9.44 \\
\hline night gown & 0.2 & 127.4 & 420.03 & 229.69 & 212.65 & 17.04 & 200 & 110.02 & 56.99 \\
\hline $\mathrm{t}$-shirt & 0.8 & 124.5 & 236.43 & 89.90 & 57.44 & 32.46 & 236 & 0.18 & 89.56 \\
\hline women's handbag & 0.3 & 402.3 & 603 & 49.89 & 285.81 & -235.92 & 325 & 85.54 & -19.21 \\
\hline Total & 5.6 & & & 259.86 & 229.00 & 30.86 & & 165.13 & 47.40 \\
\hline \multicolumn{10}{|l|}{ Shoes } \\
\hline men's walking shoes & 1.1 & 347.2 & 1322 & 280.76 & 266.20 & 14.56 & 650 & 103.38 & 87.21 \\
\hline ladies' shoes & 0.3 & 276.3 & 1179.6 & 326.93 & 294.57 & 32.36 & 650 & 81.48 & 135.25 \\
\hline Total & 1.4 & & & 290.65 & 272.28 & 18.37 & & 98.69 & 97.51 \\
\hline
\end{tabular}


Table 2

(continued)

\begin{tabular}{|c|c|c|c|c|c|c|c|c|c|}
\hline $\begin{array}{l}\text { Product Description } \\
\text { (1) }\end{array}$ & $\begin{array}{c}\text { Weight } 1990 \\
\text { (2) }\end{array}$ & $\begin{array}{c}\text { Price } 1990 \\
\text { (3) }\end{array}$ & $\begin{array}{c}\text { Price } 2000 \\
\text { (4) }\end{array}$ & $\begin{array}{c}\text { \% Price Increase } \\
\text { (5) }\end{array}$ & $\begin{array}{c}\text { Index } \\
\text { Increase } \\
\text { (6) }\end{array}$ & $\begin{array}{c}\text { Captured } \\
\text { Change } \\
(7)\end{array}$ & $\begin{array}{c}\text { Today's Price } \\
\text { for 1990 Product } \\
(8)\end{array}$ & $\begin{array}{l}\text { \% Quality } \\
\text { Change } \\
\text { (9) }\end{array}$ & $\begin{array}{c}\% \text { Actual } \\
\text { Price Increase } \\
(10)\end{array}$ \\
\hline \multicolumn{10}{|l|}{ Accommodation } \\
\hline hotel class $\mathrm{B} / * * *$ & 0.1 & 128.2 & 1082 & 743.99 & 638.34 & 105.65 & 700 & 54.57 & 446.02 \\
\hline latex painting & 0.8 & 14.2 & 43.2 & 204.23 & 214.04 & -9.81 & 17.5 & 146.86 & 23.24 \\
\hline Total & 0.9 & & & 264.20 & 261.18 & 3.02 & & 136.60 & 70.22 \\
\hline \multicolumn{10}{|l|}{ Household } \\
\hline kitchen unit & 4 & 4294.9 & 17705 & 312.23 & 286.51 & 25.72 & 7000 & 152.93 & 62.98 \\
\hline bed for kids & 0.2 & 390 & 2865 & 634.62 & 613.91 & 20.71 & 2000 & 43.25 & 412.82 \\
\hline electric bulb & 4.1 & 4.8 & 11.1 & 131.25 & 132.58 & -1.33 & 11.1 & 0.00 & 131.25 \\
\hline table lamp & 1.4 & 258 & 530.38 & 105.57 & 111.17 & -5.60 & 400 & 32.60 & 55.04 \\
\hline Total & 9.7 & & & 212.56 & 202.89 & 9.66 & & 68.66 & 97.91 \\
\hline \multicolumn{10}{|l|}{ Dry Goods } \\
\hline cotton sheet, pillow case & 0.2 & 253 & 452 & 78.66 & 75.39 & 3.27 & 490 & -7.76 & 93.68 \\
\hline towel & 1.4 & 32 & 111.5 & 248.44 & 237.13 & 11.31 & 111.5 & 0.00 & 248.44 \\
\hline Total & 1.6 & & & 227.21 & 216.91 & 10.30 & & -0.97 & 229.09 \\
\hline
\end{tabular}


Table 2

(continued)

\begin{tabular}{|c|c|c|c|c|c|c|c|c|c|}
\hline $\begin{array}{c}\text { Product Description } \\
\text { (1) }\end{array}$ & $\begin{array}{c}\text { Weight } 1990 \\
\text { (2) }\end{array}$ & $\begin{array}{c}\text { Price } 1990 \\
\text { (3) }\end{array}$ & $\begin{array}{c}\text { Price } 2000 \\
\text { (4) }\end{array}$ & $\begin{array}{c}\text { \% Price Increase } \\
\text { (5) }\end{array}$ & $\begin{array}{c}\text { Index } \\
\text { Increase } \\
(6)\end{array}$ & $\begin{array}{c}\text { Captured } \\
\text { Change } \\
(7)\end{array}$ & \begin{tabular}{|c|} 
Today's Price \\
for 1990 Product \\
$(8)$
\end{tabular} & $\begin{array}{c}\text { \% Quality } \\
\text { Change } \\
(9)\end{array}$ & $\begin{array}{c}\text { \% Actual } \\
\text { Price Increase } \\
\text { (10) }\end{array}$ \\
\hline \multicolumn{10}{|l|}{ Home Appliances } \\
\hline washing machine & 2.8 & 6067.7 & 14480 & 138.64 & 132.55 & 6.09 & 9500 & 52.42 & 56.57 \\
\hline refridgerator & 2.6 & 5720.4 & 10000 & 74.81 & 61.44 & 13.37 & 4970 & 101.21 & -13.12 \\
\hline vacuumcleaner & 0.9 & 1606.3 & 3842 & 139.18 & 100.02 & 39.16 & 2000 & 92.10 & 24.51 \\
\hline safety razor & 0.2 & 411.4 & 2150.5 & 422.73 & 373.03 & 49.70 & 650 & 230.85 & 58.00 \\
\hline electric iron & 0.6 & 160.4 & 1982 & 1135.66 & 1230.82 & -95.16 & 900 & 120.22 & 461.10 \\
\hline Total & 7.3 & & & 204.86 & 198.27 & 6.59 & & 86.38 & 59.68 \\
\hline \multicolumn{10}{|l|}{ Electrical Supplies } \\
\hline battery & 1.1 & 1.7 & 6.97 & 310.00 & 329.67 & -19.67 & 1.9 & 266.84 & 11.76 \\
\hline \multicolumn{10}{|l|}{ Home Care Products } \\
\hline washing powder & 2.1 & 13.2 & 86.4 & 554.55 & 537.61 & 16.94 & 40 & 116.00 & 203.03 \\
\hline detergent for dishes & 1.2 & 10 & 64.46 & 544.60 & 520.38 & 24.22 & 20 & 222.30 & 100.00 \\
\hline drycleaning & 0.2 & 22.4 & 63.3 & 182.59 & 177.26 & 5.33 & 47.5 & 33.26 & 112.05 \\
\hline Total & 3.5 & & & 529.88 & 511.11 & 18.77 & & 147.72 & 162.51 \\
\hline
\end{tabular}


Table 2

(continued)

\begin{tabular}{|c|c|c|c|c|c|c|c|c|c|}
\hline $\begin{array}{l}\text { Product Description } \\
\text { (1) }\end{array}$ & $\begin{array}{c}\text { Weight } 1990 \\
\text { (2) }\end{array}$ & $\begin{array}{c}\text { Price } 1990 \\
\text { (3) }\end{array}$ & $\begin{array}{c}\text { Price } 2000 \\
\text { (4) }\end{array}$ & $\begin{array}{c}\text { \% Price Increase } \\
\text { (5) }\end{array}$ & $\begin{array}{c}\text { Index } \\
\text { Increase } \\
\text { (6) }\end{array}$ & $\begin{array}{l}\text { Captured } \\
\text { Change } \\
(7)\end{array}$ & $\begin{array}{c}\text { Today's Price } \\
\text { for 1990 Product } \\
(8)\end{array}$ & $\begin{array}{c}\text { \% Quality } \\
\text { Change } \\
\text { (9) }\end{array}$ & $\begin{array}{c}\% \text { Actual } \\
\text { Price Increase } \\
\text { (10) }\end{array}$ \\
\hline Transport & & & & & & & & & \\
\hline personal car Skoda & 25.3 & 86708.1 & 260000 & 199.86 & 155.09 & 44.77 & 135000 & 92.59 & 55.69 \\
\hline bike for kids & 0.5 & 816.8 & 3535 & 332.79 & 246.28 & 86.51 & 2650 & 33.40 & 224.44 \\
\hline repair of car brakes & 1.6 & 296 & 1115 & 276.69 & 264.00 & 12.69 & 1000 & 11.50 & 237.84 \\
\hline Total & 27.6 & & & 206.61 & 163.09 & 43.52 & & 86.72 & 69.33 \\
\hline Recreational Products & & & & & & & & & \\
\hline color TV & 9.3 & 12276.8 & 11485 & -6.45 & -5.53 & -0.92 & 2750 & 317.64 & -77.60 \\
\hline videorecorder & 1.6 & 8371.7 & 10420 & 24.47 & 21.57 & 2.90 & 2350 & 343.40 & -71.93 \\
\hline cinefilm & 2.1 & 46.3 & 114.43 & 147.15 & 145.82 & 1.33 & 50 & 128.86 & 7.99 \\
\hline cross country ski & 1.2 & 579.2 & 1570 & 171.06 & 138.49 & 32.57 & 800 & 96.25 & 38.12 \\
\hline rose & 0.4 & 10.6 & 39.75 & 275.00 & 266.95 & 8.05 & 30 & 32.50 & 183.02 \\
\hline Total & 15.6 & & & 36.65 & 34.16 & 2.49 & & 266.78 & -50.13 \\
\hline Amusement Services & & & & & & & & & \\
\hline cinema ticket & 0.1 & 16 & 55.21 & 245.06 & 240.31 & 4.75 & 32.5 & 69.88 & 103.13 \\
\hline MF daily & 1.8 & 2.5 & 7.5 & 200.00 & 200.00 & 0.00 & 3.8 & 97.37 & 52.00 \\
\hline Total & 1.9 & & & 202.37 & 202.12 & 0.25 & & 95.92 & 54.69 \\
\hline
\end{tabular}


Table 2

(continued)

\begin{tabular}{|c|c|c|c|c|c|c|c|c|c|}
\hline $\begin{array}{l}\text { Product Description } \\
\text { (1) }\end{array}$ & $\begin{array}{c}\text { Weight } 1990 \\
\text { (2) }\end{array}$ & $\begin{array}{c}\text { Price } 1990 \\
\text { (3) }\end{array}$ & $\begin{array}{c}\text { Price } 2000 \\
\text { (4) }\end{array}$ & $\begin{array}{c}\% \text { Price Increase } \\
\text { (5) }\end{array}$ & $\begin{array}{c}\text { Index } \\
\text { Increase } \\
(6)\end{array}$ & $\begin{array}{l}\text { Captured } \\
\text { Change } \\
(7)\end{array}$ & \begin{tabular}{|c|} 
Today's Price \\
for 1990 Product \\
$(8)$
\end{tabular} & $\begin{array}{l}\text { \% Quality } \\
\text { Change } \\
(9)\end{array}$ & $\begin{array}{c}\text { \% Actual } \\
\text { Price Increase } \\
(\mathbf{1 0})\end{array}$ \\
\hline Personal Care Products & & & & & & & & & \\
\hline toothpaste & 1.1 & 3.4 & 14.3 & 320.59 & 291.30 & 29.29 & 8 & 78.75 & 135.29 \\
\hline soap & 0.3 & 66 & 24.8 & -62.42 & 224.54 & -286.96 & 18 & 37.78 & -72.73 \\
\hline hair shampoo & 0.6 & 17.1 & 31 & 81.29 & 47.31 & 33.98 & 27 & 14.81 & 57.89 \\
\hline paper tissues & 0.3 & 3.9 & 17.57 & 350.51 & 365.05 & -14.54 & 8 & 119.63 & 105.13 \\
\hline Total & 9 & & & 71.25 & 70.65 & 0.60 & & 289.07 & -33.38 \\
\hline Total weight & 161.9 & & & 149.99 & 139.41 & 10.58 & & 84.17 & 65.95 \\
\hline
\end{tabular}

